\title{
Evaluation of the efficacy and patient satisfaction of the intracavernosal alprostadil in the treatment of erectile dysfunction following robot-assisted radical prostatectomy
}

\author{
Robot yardımlı transperitoneal radikal prostatektomi sonrası erektil disfonksiyon tedavisinde \\ intrakavernozal alprostatilin etkinliği ve hasta memnuniyetinin değerlendirilmesi
}

\author{
Hüseyin Kocatürk', Mehmet Sefa Altay', Fevzi Bedir', Banu Bedir² \\ 1 University of Health Sciences, Department of Urology, Erzurum Regional Training and Research Hospital, Erzurum, Turkey \\ 2 Aziziye District Health Directorate, Erzurum, Turkey
}

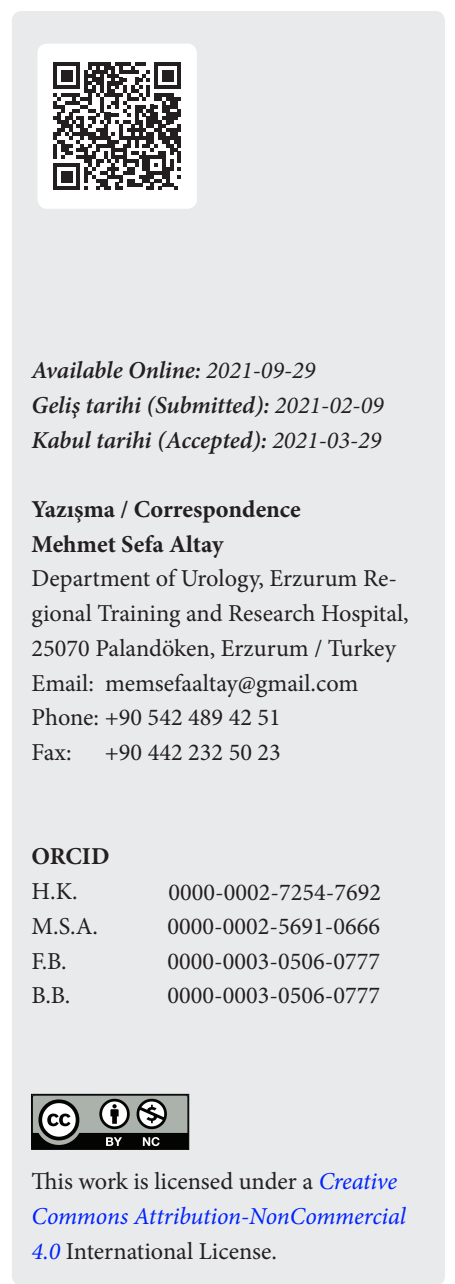

\section{Özet}

Amaç: Robot yardımlı radikal prostatektomi (RARP) sonrası erektil disfonksiyon (ED) önemli bir problem olup, bu çalışmada ED tedavisinde kullanılan intrakavernozal alprostadilin etkinliğini ve hasta memnuniyetini değerlendirmeyi amaçladık.

Gereç ve Yöntemler: RARP sonrası ED tedavisinde intrakavernozal alprostadil kullanan hastalar retrospektif olarak değerlendirildi. Hastaların demografik özellikleri, operasyon öncesi ve sonrasi International Index of Erectile Function (IIEF) skorları ve genel memnuniyeti IIEF form 13. ve 14. soruları ile değerlendirilerek kayıt altına alındı. Tedavi sürecinde gelişen komplikasyonlar, kullanım dozları ve bırakma nedenleri incelendi.

Bulgular: Araştırmaya toplam 34 hasta alındı. Hastaların yaş ortalaması $61.73 \pm 5.80$ yıldı. Hastaların $\% 52.9^{\prime}$ unda ( $\mathrm{n}=18$ ) preoperatif ED tespit edildi. Hastaların preoperatif, postoperatif 1 . ay, postoperatif 3 ay tadalafil kullanımı sonrası ve intrakavernozal alprostadil kullanan hastaların IEFF ortalaması sırasiyla $20.64 \pm 3.46,15.08 \pm 2.09,15.32 \pm 2.18,26.67 \pm 2.30$ ' du. Hastaların intrakavernozal Alprostadil kullanma sürelerinin ortalaması $8.20 \pm 2.48$ ay' dive $\% 70.58$ 'inde tam ereksiyon sağladığı görüldü. İntrakavernozal Alprostadil kullanımına bağlı hastaların, \%2.9'unda hematom, \%8.8'inde ekimoz, \%11.8'inde ağrı geliști. Hastaların takip süresi içerisinde \% 73.5 'inin ilaca devam ettiği tespit edildi. Hastaların alprostadil tedavisi sonrası istatistiksel olarak anlamlı derecede genel memnuniyetlerinin yüksek olduğu görüldü.

\section{Abstract}

Objective: Erectile dysfunction (ED) following robot-assisted radical prostatectomy (RARP) is an important problem. The purpose of this study was to evaluate the effectiveness of and patient satisfaction with intracavernosal alprostadil used in the treatment of ED.

Material and Methods: Patients using intracavernosal alprostadil in the treatment of ED following RARP were assessed retrospectively. Patients' demographic characteristics, pre- and postoperative International Index of Erectile Function (IIEF) scores, and general satisfaction evaluated using questions 13 and 14 of the IIEF form were all recorded. Complications developing during treatment, dosages used, and reasons for discontinuation were investigated.

Results: Thirty-four patients with a mean age of $61.73 \pm 5.80$ years were included in the study. Preoperative ED was determined in $52.9 \%(n=18)$ of patients. The mean IEFF of the patients who used preoperative, postoperative 1st month, postoperative 3 months after tadalafil use and intracavernosal alprostadil was $20.64 \pm 3.46,15.08 \pm 2.09$, $15.32 \pm 2.18,26.67 \pm 2.30$, respectively. The mean length of use of intracavernosal alprostadil was $8.20 \pm 2.48$ months, and full erection was achieved in $70.58 \%$ of patients. Hematoma associated with intracavernosal alprostadil use developed in $2.9 \%$ of patients, ecchymosis in $8.8 \%$, and pain in $8.8 \%$. In addition, $73.5 \%$ of patients continued to take their medication during the follow-up process. Patients' general satisfaction following alprostadil therapy was statistically significantly high. 
Sonuç: RARP sonrası, intrakavernozal alprostatil tedavisi, tam ereksiyon sağlamada sonuçlarının yüksek olması, düşük komplikasyon oranları ve yüksek hasta memnuniyeti ile iyi bir tedavi seçeneğidir.

Anahtar Kelimeler: Alprostadil, erektil disfonksiyon, robot yardımlı radikal prostatektomi.
Conclusion: Intracavernosal alprostadil therapy following RARP represents a good therapeutic option due to its high success in achieving full erection, low complication rates, and high patient satisfaction.

Keywords: Alprostadil, erectile dysfunction, robot-assisted radical prostatectomy.

\section{INTRODUCTION}

Erectile dysfunction (ED) is defined as the inability to achieve or maintain penile erection necessary for successful sexual intercourse and is a common disease with a prevalence of up to $53 \%$ in men over the age of $40(1,2)$. A normal erection depends on complete equilibrium among psychogenic, hormonal, neurological, vascular, and cavernosal factors. Impairment of any one of these factors results in ED (2). Although the etiology of ED is multifactorial, the vascular component predominates. Hypertension, diabetes mellitus, hyperlipidemia, and smoking, causes of the development of arteriosclerosis, are therefore the principal risk factors for $\mathrm{ED}(3)$.

The mechanism involved in ED developing following radical prostatectomy or cystoprostatectomy is generally neurological in origin, but may also be vascular in origin in cases of injury to the pudendal artery and its branches (4). Postoperative ED rates are decreasing due to nerve preservation as techniques improve. However, despite all these techniques, postoperative erectile capacity is known to range between $35 \%$ and $60 \%$, depending on the patient's clinical and pathological stage, preoperative erectile capacity, or age $(4,5)$. Restoration of erectile capacity in the postoperative period takes 12-18 months, and various oral or intracavernosal drugs and penile rehabilitation are employed to shorten this period and prevent cavernosal fibrosis (6).

Intracavernosal agents are used as mono- or combination therapy, in the form of prostaglandin E1 (PGE1), papaverine, phentolamine, vasoactive intestinal peptides, and nitric oxide donors. Alprostadil, is a synthetic form of PGE1. PGE1 stimulated adenylate cyclase with 3'5'-cAMP formation, and inhibits the release of noradrenaline in alpha 1-adrenoceptors by means of presynaptic prostaglandin receptors. In ad- dition, it results in impairment of smooth muscle tone by inhibiting angiotensin II secretion, and membrane hyperpolarization as a result of potassium ion channel stimulation. It also exhibits anti-collagen and thus antifibrotic effects by inhibiting transforming growth factor $\beta 1$ (TGF- $\beta 1$ ) (7).

In parallel to the development of alprostadil monotherapy, PGE1/papaverine/phentolamine combinations are also currently employed. Automatic injectors have been developed for ED patients regarded as suitable for injection therapy in order to make the process and simple and painless as possible and easily follow-up, and to permit long-term use. The purpose of this study was to evaluate the effectiveness of and patient satisfaction with intracavernosal alprostadil used in the treatment of ED following robot-assisted transperitoneal radical prostatectomy (RARP).

\section{MATERIAL AND METHODS}

This retrospective, single-center study was performed following receipt of ethical committee approval (2021/03-58). Demographic characteristics and pre- and postoperative International Index of Erectile Function (IIEF) scores were evaluated from patients' files. Patients' general satisfaction was recorded by examining IIEF form questions 13 and 14 .

ED patients started on $5 \mathrm{mg}$ tadalafil following radical prostatectomy but not responding or responding insufficiently were started on $5 \mu \mathrm{g}$ intracavernosal alprostadil due to potential complications and in terms of drug adherence. The dosage in patients with unsuccessful or inadequate attempted sexual intercourse was increased by $2.5 \mu \mathrm{g}$ at one-day intervals until a successful response achieved. Patients started on intracavernosal therapy were given detailed information about prolonged erection and potential complications, and were invited to attend routine controls once month- 
ly in the first three months, and every three months thereafter. Patients whose neurovascular bundles were preserved during RARP were included in the study. Alprostadil therapy was initiated when no response or an inadequate response to oral $5 \mathrm{mg}$ tadalafil therapy for at least three months was achieved. Patients included in the study were selected from a group participating in and completing applied training involving hand-eye coordination and self-injection before starting intracavernosal therapy. Patients with no interruptions to the study protocol were included. Patients unable to perform self-injection, with histories of cardiovascular or cerebrovascular disease, receiving anticoagulant therapy, with drug hypersensitivity, or failing to comply with the study protocol were excluded.

Patients' IIEF scores after intracavernosal therapy were investigated. Complications developing, frequencies of medication use, length of medication use, and reasons for discontinuation if applicable were recorded.

\section{Alprostadil Application Protocol}

The site of alprostadil application was first sterilized. Next, injection was performed to a vein-free region in the proximal and lateral penis using a ready-to-use automatic injector system (Cavarject ${ }^{\ominus}$, Pfizer) with a 29 gauge needle containing $10 \mu \mathrm{g}$ alprostadil. Application commenced with $5 \mu \mathrm{g}$, this being increased by $2.5 \mu \mathrm{g}$ at one-day intervals in cases with unsuccessful or inadequate sexual intercourse, with a maximum weekly dosage of $20 \mu \mathrm{g}$. These were applied to the proximal lateral aspect of the penis, a different region being used at each application. Efforts were made to prevent post-injection bleeding by compressing the needle site.

\section{Statistical Analysis}

The research data were analyzed on Statistical Package for the Social Sciences (SPSS) v20 for Windows software. Categorical variables were expressed as number and percentage, and numerical variables as mean plus standard deviation. Suitability for analysis of numerical variables was assessed using the Kolmogorov Smirnov test. The Wilcoxon test was employed for the comparison of numerical variables. P values $<0.05$ were regarded as statistically significant.

\section{RESULTS}

Thirty-four patients were included in the study. The patients' mean age was $61.73 \pm 5.80$ years, and mean body mass index (BMI) was $27.91 \pm 4.16 \mathrm{~kg} / \mathrm{m}^{2}$. Regulated hypertension was present in $20.5 \%(n=7)$ of patients, and no additional comorbidity was detected. Preoperative $\mathrm{ED}$ was determined in $52.9 \%(\mathrm{n}=18)$ of patients.

Bilateral neurovascular bundle preservation was applied to $52.9 \%$ of patients, right-side preservation to $29.4 \%$, and left-side preservation to $17.6 \%$. Patients' mean preoperative IIEF score was $20.64 \pm 3.46$, decreasing significantly to $15.08 \pm 2.09$ at one month postoperatively $(\mathrm{p}<0.001)$. The mean IIEF score among patients using tadalafil for three months was $15.32 \pm 2.18$. A small but statistically significant difference was detected between mean preoperative IIEF values $(\mathrm{p}<0.001)$.

The mean length of intracavernosal alprostadil use was $8.20 \pm 2.48$ months. The mean IIEF value among patients using intracavernosal alprostadil was $26.67 \pm 2.30$. The mean IIEF score patients using intracavernosal alprostadil differed significantly from mean preoperative scores, postoperative first month scores and postoperative 3 month scores patients using tadalafil $(\mathrm{p}<0.001)$ (Table 1). Full erection was achieved in $70.58 \%$ of our patients.

Intracavernosal alprostadil use-related hematoma developed in $2.9 \%$ of patients, ecchymosis in $8.8 \%$, and pain complications in $11.8 \%$. Sufficient response was achieved with $5 \mu \mathrm{g}$ intracavernosal alprostadil in $61.8 \%$ of patients, with $7.5 \mu \mathrm{g}$ in $26.5 \%$, and with $10 \mu \mathrm{g}$ in $11.7 \%$ (Table 2).

Analysis showed that $73.5 \%$ of patients continued to use medication during follow-up, $11.8 \%$ discontinued drug use for economic reasons, $8.8 \%$ discontinued drug use since they no longer felt the need for it, and $5.9 \%$ discontinued their medication due to the death of their spouses (Table 2).

Patients' mean satisfaction scores were $7.76 \pm 1.63$ preoperatively, decreasing significantly to $4.11 \pm 0.84$ at one month postoperatively $(\mathrm{p}<0.001)$. The mean satisfaction score among patients using tadalafil for three months was $4.17 \pm 0.90$, a significant decrease compared to preoperative satisfaction levels $(\mathrm{p}<0.001)$. The mean satisfaction score of patients using intracavernosal 
alprostadil was $9.05 \pm 1.32$, a significant increase compared to preoperative values $(\mathrm{p}<0.001)$. A significant difference was detected between tadalafil users' postoperative first and third month mean satisfaction scores $(\mathrm{p}=0.011)$. Mean satisfaction scores among patients using tadalafil and among those using intracavernosal alprostadil both increased significantly between one and three months postopertively $(\mathrm{p}<0.001)$ (Table 1$)$.

Table 1. Patients' demographic characteristics, pre- and postoperative IIEF, and general satisfaction results

\begin{tabular}{lll}
\hline & Min-max(median) & Mean \pm SD \\
\hline Age & $51-73(62)$ & $61.73 \pm 5.80$ \\
BMI & $21-36(28)$ & $27.91 \pm 4.16$ \\
Preoperative IIEF score & $15-26(20.5)$ & $20.64 \pm 3.46$ \\
Postoperative 1st month IIEF score & $12-19(15)$ & $15.08 \pm 2.09$ \\
IIEF values in patients using 3-month postoperative tadalafil & $12-20(15)$ & $15.32 \pm 2.18$ \\
IIEF values in patients using 3-month postoperative alprostadil & $23-30(27)$ & $26.67 \pm 2.30$ \\
Length of alprostadil use (months) & $3-12(9)$ & $8.20 \pm 2.48$ \\
Preoperative (general satisfaction) & $4-10(6)$ & $7.76 \pm 1.63$ \\
Postoperative (general satisfaction) & $2-6(4)$ & $4.11 \pm 0.84$ \\
Using postoperative 3-month tadalafil (general satisfaction) & $2-6(4)$ & $4.17 \pm 0.90$ \\
Using postoperative 3-month alprostadil (general satisfaction) & $6-10(10)$ & $9.05 \pm 1.32$ \\
\hline
\end{tabular}

IIEF=International Index of Erectile Function

Table 2. Intracavernosal dosages of alprostadil and reasons for discontinuation

\begin{tabular}{lcc}
\hline & $\mathbf{n}$ & $\%$ \\
\hline Alprostadil dosage & & \\
\hline $5 \mu \mathrm{g}$ & 21 & 61.8 \\
$7.5 \mu \mathrm{g}$ & 9 & 26.5 \\
$10 \mu \mathrm{g}$ & 4 & 11.7 \\
\hline Alprostadil use status & 25 & 73.5 \\
\hline Continuing to use & 4 & 11.8 \\
Discontinuing for economic reasons & 3 & 8.8 \\
Discontinuing due to no longer needing the drug & 2 & 5.9 \\
Discontinuing due to loss of spouse & 25 \\
\hline
\end{tabular}

\section{DISCUSSION}

Prostate cancer $(\mathrm{PCa})$ is one of the most common cancers among men in developed countries. ED is one of the most important and most difficult to treat complications of radical prostatectomy performed for local PCa (8). Although postoperative ED rates are decreas- ing with the development of nerve preserving techniques, it is still an important problem. Patients should be evaluated in terms of ED prior to surgery, and their expectations in the postoperative period and their IIEF scores for therapeutic success must be recorded. 
ED is known to develop in $35-60 \%$ of men undergoing radical prostatectomy $(\mathrm{RP})(4,5)$. Phosphodiesterase type 5 inhibitors (PDE5I) are most commonly employed in medical treatment, together with vacuum devices, local or intraurethral alprostadil, low-energy extracorporeal shock wave therapy (Li-ESWT), intracavernosal injections, and combination therapies (6). Alprostadil is used in the form of intraurethral gel or intracavernosal injection in erection evaluation following radical prostatectomy. Alprostadil may be employed in patients in whom oral pharmacotherapy is unsuccessful, or who are contraindicated or intolerant, who have spinal cord injuries, or in ED patients after radical prostatectomy (2). Penile rehabilitation is defined as achieving maximal improvement in erectile function by the use of various medications or devices following RP (9). Penile rehabilitation increases cavernosal oxygenation and prevents irreversible changes in endothelial and smooth muscles (10). Montorsi et al. showed that local alprostadil use in the early postoperative period significantly increased penile function (11). A penile rehabilitation program must be initiated as soon as possible after surgery in order to limit fibrotic changes leading to ED.

The most important risk factors for ED are advanced age, cardiovascular disease, and diabetes mellitus $(12,13)$. Young age and low BMI are protective factors in terms of ED (14). Studies investigating the effect of age on postoperative erectile function have reported improvement in $70 \%$ of patients under 60 , in $40 \%$ of patients aged $60-65$, and in $30 \%$ of those aged over 65 (15). The mean age of the patients in the present study was $61.73 \pm 5.80$, regulated hypertension was present in $20.5 \%(n=7)$, but no additional comorbidities were detected. Preoperative ED was also detected in $52.9 \%$ of patients.

The first-line treatment in ED is lifestyle changes, with PDE5 inhibitors representing second-line treatment. Alprostadil or papaverine are used in case of PDE5 inhibitor contraindication and/or inadequate response (16). Alprostadil is a synthetic PGE1 form providing smooth muscle relaxation, with reported success rates in $\mathrm{ED}$ of $70-80 \%$ at dosages of 2,5-20 $\mu \mathrm{g}$, the dosage being adjusted depending on the patient and the underlying pathology. It can be applied once daily, or at most 1-2 times a week $(17,18)$. It was first used by Montorsi in 1997 (19). In the present study, alprostadil used in the treatment of ED following RARP achieved a full erection rate of $70.58 \%$.

Due to the difficult nature of intracavernosal therapy, and its side-effects and costs, it is known to be discontinued in $30-80 \%$ of cases (20). One study reported a drug discontinuation rate of $31 \%$ with close follow-up and free-of-charge drug support (21). In the present study, $73.5 \%$ of patients continued with their medication, while $11.8 \%$ discontinued it for economic reasons, $8.8 \%$ because they no longer felt the need for treatment, and 5.9\% due to loss of their spouse.

Intracavernosal alprostadil therapy has a number of side-effects. One study reported an incidence of pain in the injection site or during erection of $11 \%$, hematoma or ecchymosis at $1.5 \%$, priapism (defined as a painful erection exceeding $4 \mathrm{~h}$ in duration) at $1.5 \%$, and penile plaque at $2 \%(21)$. Another study reported penile pain and priapism at a rate of $6.4 \%$ (22). Bearelly et al. reported that plaque or scar formation was $10 \%$, pain $2 \%$, ecchymosis $<1 \%$, irritability $<1 \%$, headache $<1 \%$ and tissue damage $<1 \%$ (17). That study also reported 1.44-inch shortening in penile length in $27 \%$ of patients and penile curvature in $20 \%$. Hematoma was present in $2.9 \%$ of patients in the present study, ecchymosis in $8.8 \%$, and pain in $11.8 \%$, but no other complications were observed.

Studies comparing intracavernosal injection with oral therapy have reported significant improvements in satisfaction and IIEF scores. Mulhall et al. reported a high IIEF score of $66 \pm 5$, and Bearelly et al. of 60.0 $\pm 10.95(17,23)$. In addition, Kucuk et al. reported higher IIEF scores with intracavernosal therapies compared to PDE5I inhibitors (24). Alexandre et al. reported $78 \%$ patient satisfaction and that $86 \%$ of patients would recommend the treatment, while Bearelly et al. reported patient satisfaction of $88 \%$ and that $94 \%$ of patients would recommend the treatment $(17,25)$. Our patients' IIEF scores decreased significantly postoperatively compared to the preoperative period. However, these decreasing IIEF scores increased significantly in patients using alprostadil. The improvement in IIEF 
scores among patients using postoperative intracavernosal alprostadil was greater than that in patients using postoperative tadalafil. As shown in Table 1, patients' mean general satisfaction increased significantly following intracavernosal alprostadil therapy.

There are a number of limitations to the present study, including the low patient number and its retrospective and single-center design. However, we think that intracavernosal alprostadil therapy does not occupy a sufficient place in urological practice, and that it requires better investigation in terms of effectiveness, outcomes, and patient satisfaction. We believe that further prospective, randomized control studies are needed on this subject, and that our own findings will make a significant contribution to the current literature.

\section{CONCLUSION}

Intracavernosal alprostadil therapy used after RARP is a good option providing good results in terms of achieving full erection, low complication rates, and high patient satisfaction. However, areas requiring improvement are the drug's high costs and high discontinuation rates.

\section{Conflict of Interest}

The authors declare to have no conflicts of interest.

\section{Financial Disclosure}

The authors declared that this study has received no financial support.

\section{Informed Consent}

Informed consent was obtained from all individual participants included in the study.

\section{Ethical Approval}

The study was approved by the ethics committee of the University of Health Sciences, Erzurum Regional Education and Research Hospital (Approval number: 2021/0358) and written informed consent was received from all participants. The study protocol conformed to the ethical guidelines of the Helsinki Declaration.

\section{Author Contributions}

Conception and design; HK, MSA, FB, Data acquisition; HK, MSA, Data analysis and interpretation; MSA, FB, BB, Drafting the manuscript; HK, MSA, FB, Critical revision of the manuscript for scientific and factual content; MSA, FB, Statistical analysis; FB, BB, Supervision; MSA.

\section{REFERENCES}

1. Shamloul R, Ghanem H. Erectile dysfunction. Lancet. 2013; 381:153-65.

2. Sandoval-Salinas C, Saffon JP, Corredor HA. Quality of Clinical Practice Guidelines for the Diagnosis and Treatment of Erectile Dysfunction: A Systematic Review. J Sex Med 2020; 17: 678-87.

3. Diniz AFA, Ferreira RC, de Souza ILL, da Silva BA. Ionic Channels as Potential Therapeutic Targets for Erectile Dysfunction: A Review. Front Pharmacol 2020;11: 1120.

4. Gratzke C, Angulo J, Chitaley K et al. Anatomy, physiology, and pathophysiology of erectile dysfunction. J Sex Med 2010;7:445-75.

5. Burnett AL. Erectile dysfunction. J Urol 2006;175:25-31.

6. Baccaglini W, Pazeto CL, Corrêa Barros EA et al. The Role of the Low-Intensity Extracorporeal Shockwave Therapy on Penile Rehabilitation After Radical Prostatectomy: A Randomized Clinical Trial. J Sex Med 2020;17:688-94.

7. Porst H. Current perspectives on intracavernosal pharmacotherapy for erectile dysfunction. Int J Impot Res 2000;12 Suppl 4:91-100.

8. Mottet N, van den Bergh RCN, Briers E et al. EAUEANM-ESTRO-ESUR-SIOG Guidelines on Prostate Cancer-2020 Update. Part 1: Screening, Diagnosis, and Local Treatment with Curative Intent. Eur Urol 2020.

9. Clavell-Hernandez J, Wang R. Penile rehabilitation following prostate cancer treatment: review of current literature. Asian J Androl 2015;17:916-22.

10. Bratu O, Oprea I, Marcu D et al. Erectile dysfunction post-radical prostatectomy - a challenge for both patient and physician. J Med Life 2017;10:13-8.

11. Montorsi F, Guazzoni G, Strambi LF et al. Recovery of spontaneous erectile function after nerve-sparing rad- 
ical retropubic prostatectomy with and without early intracavernous injections of alprostadil: results of a prospective, randomized trial. J Urol 1997;158:1408-10.

12. Vlachopoulos C, Jackson G, Stefanadis C, Montorsi P. Erectile dysfunction in the cardiovascular patient. Eur Heart J 2013;34:2034-46.

13. Maiorino MI, Bellastella G, Esposito K. Diabetes and sexual dysfunction: current perspectives. Diabetes Metab Syndr Obes 2014;7:95-105.

14. Medina-Polo J, García-Gómez B, Alonso-Isa M, Romero-Otero J. Clinical guidelines on erectile dysfunction surgery: EAU-AUA perspectives. Actas Urol Esp 2020;44:289-93.

15. Rabbani F, Stapleton AM, Kattan MW et al. Factors predicting recovery of erections after radical prostatectomy. J Urol 2000;164:1929-34.

16. Hatzimouratidis K, Salonia A, Adaikan G et al. Pharmacotherapy for Erectile Dysfunction: Recommendations From the Fourth International Consultation for Sexual Medicine (ICSM 2015). J Sex Med 2016;13:465-88.

17. Bearelly P, Phillips EA, Pan S et al. Long-term intracavernosal injection therapy: treatment efficacy and patient satisfaction. Int J Impot Res 2020;32:345-51.

18. Khera M, Goldstein I. Erectile dysfunction. BMJ Clin Evid 2011;2011.

19. Montorsi F, Salonia A, Zanoni M et al. Current status of local penile therapy. Int J Impot Res 2002;14:70-81.
20. Mulhall JP, Jahoda AE, Cairney $M$ et al. The causes of patient dropout from penile self-injection therapy for impotence. J Urol 1999;162:1291-4.

21. Linet OI, Ogrinc FG. Efficacy and safety of intracavernosal alprostadil in men with erectile dysfunction. The Alprostadil Study Group. N Eng J Med 1996;334:873-7.

22. Taşkapu HH, Sönmez MG, Kılınç MT et al. Efficiency of intracavernosal alprostadil and oral clomiphene citrate combination treatment in penile vasculogenic erectile dysfunction patients accompanied by late-onset hypogonadism. Andrologia 2020;52: e13759.

23. Mulhall JP, Simmons J. Assessment of comparative treatment satisfaction with sildenafil citrate and penile injection therapy in patients responding to both. BJU Int 2007;100:1313-6.

24. Kucuk EV, Tahra A, Bindayi A, Onol FF. Erectile dysfunction patients are more satisfied with penile prosthesis implantation compared with tadalafil and intracavernosal injection treatments. Andrology 2016;4:952-6.

25. Alexandre B, Lemaire A, Desvaux P, Amar E. Intracavernous injections of prostaglandin E1 for erectile dysfunction: patient satisfaction and quality of sex life on long-term treatment. J Sex Med 2007;4:426-31. 